Rainer Schlittgen

Angewandte Zeitreihenanalyse mit R 



\section{Rainer Schlittgen}

Angewandte

Zeitreihenanalyse mit R

3., aktualisierte und erweiterte Auflage

OLDENBOURG 
ISBN 978-3-11-041398-4

e-ISBN (PDF) 978-3-11-041399-1

e-ISBN (EPUB) 978-3-11-042377-8

\section{Library of Congress Cataloging-in-Publication Data}

A CIP catalog record for this book has been applied for at the Library of Congress.

Bibliografische Information der Deutschen Nationalbibliothek

Die Deutsche Nationalbibliothek verzeichnet diese Publikation in der Deutschen Nationalbibliografie; detaillierte bibliografische Daten sind im Internet über http://dnb.dnb.de abrufbar.

(c) 2015 Walter de Gruyter GmbH, Berlin/München/Boston Einbandabbildung: Autor Druck und Bindung: $\mathrm{CPI}$ books $\mathrm{GmbH}$, Leck ๑) Gedruckt auf säurefreiem Papier Printed in Germany

www.degruyter.com 